Irena Matus

Biatystok

\title{
Obraz Cerkwi unickiej w obwodzie białostockim na początku XIX wieku
}

Słowa kluczowe: cerkiew unicka, synod zamojski, latynizacja, polonizacja

Podział Kościoła na wschodni i zachodni w 1054 roku, przypieczętowany krwawo przez IV krucjatę w roku 1204, uznawany był za ranę na żywym organizmie ustanowionej przez Chrystusa instytucji, której zaleczenie pozostawało celem wielu, kierujących się szlachetnymi ideami, ludzi [Hryniewicz 1998, 63]. Częściej jednak próby budowania kościelnej jedności miały tło polityczne. Tak było w przypadku unii lyońskiej (1274), florenckiej (1439), podobnie i brzeskiej (1596).

Historię Cerkwi unickiej można podzielić na dwa etapy. Pierwszy to okres walki z prawosławiem, budowy i umacniania jej struktur w XVII wieku, drugi z wyraźną granica, jaką wyznaczył synod zamojski 1720 roku - czas nasilonej latynizacji. Przyspieszał ją fakt, że unia była zbudowana na fundamencie Kościoła rzymskokatolickiego i wydawało się oczywiste, że wszystkie strony jej życia duchowego i obrzędowego powinny rozwijać się na wzór Kościoła łacińskiego. Troska o jego rozprzestrzenianie, umocnienie i ochronę powierzona została zgromadzeniom zakonnym. Podobnie w Cerkwi unickiej jej interesy przekazano utworzonemu w 1617 roku zakonowi bazylianów ${ }^{1}$, wzorowanemu na zgromadzeniu jezuitów [Зноско 1993, 182; Pidłypczak-Majerowicz 2010, 83]. To oni najbardziej przyczynili się do latynizacji na ziemiach białoruskich i na Podlasiu.

1 Działał on w granicach Rzeczypospolitej, po 1882 roku w zaborze austriackim, a w okresie międzywojennym w Małopolsce wschodniej, po 1945 roku został zorganizowany w prowincję polską, która posiada kilka placówek z siedzibą główną w Warszawie. 
Z perspektywy rzymskiej - podkreśla Antoni Mironowicz - Rusini zostali wcieleni, jako indywidualni chrześcijanie, do Kościoła rzymskiego pod przewodnictwem papieża. Akt ten nie przywracał sakramentalnej jedności Kościoła i Cerkwi w Rzeczypospolitej, stając się jedynie prawno-kościelnym aktem poddania się władzy papieża [Kołbuk 1998, 29]. Nie o taką unię chodziło biskupom, którzy byli jej inicjatorami. Sprawy toczyły się już jednak własnym torem. Przyrzeczenie dane unitom w czasie zawarcia unii brzeskiej, dotyczące nienaruszalności ich obrządku, tradycji Świętej Liturgii, było gwarancją „na dziś”, na pozyskanie 6-milionowej społeczności prawosławnej Rzeczypospolitej Trojga Narodów. Przyrzeczenia te były fikcją [Bendza M., 2003, 275].

Biskupi ruscy przystępując do unii pragnęli utrzymać odrębność prawno-liturgiczną swojego Kościoła, stawiając na pierwszym planie nienaruszalność obrządku. Wchodząc w jedność eklezjologiczną z Rzymem chcieli zachować wschodnie dziedzictwo, własną tożsamość, ale i pozostać we wspólnocie z innymi Kościołami prawosławnymi. Szybko przekonano się, że jest to niemożliwe a 32 artykuły przywiezione przez biskupów ruskich z Rzymu, dotyczące głównie spraw liturgicznych i dyscyplinarnych, powędrowały do archiwum [Bendza 2003, 276].

Już w 1666 roku na kongregacji w Brześciu biskup unicki Jakub Susza skarżył się, że bazylianie wnieśli tak wiele zmian do Cerkwi unickiej, zwłaszcza do Świętej Liturgii, że unickich obrzędów nie można nazwać już ani greckimi, ani łacińskimi [Зноско 1993, 182].

Uniccy hierarchowie, wbrew początkowym obietnicom, nie zostali zrównani w prawach z rzymskokatolickimi dostojnikami. Unicki metropolita Rostocki został dopuszczony do Senatu dopiero w 1790 roku, 7 września 1790 roku złożył senatorską przysięgę królowi [Dobrzański 1992, 40]. Łacinnicy upokarzali unickich hierarchów, a księża często zabierali parochom dziesięcinę [Зноско 1993, 183].

Stało się to powodem niezadowolenia duchowieństwa unickiego, które szukało wyjścia z sytuacji nawet za cenę dużych ustępstw na rzecz rzymskiego katolicyzmu. W tym celu zwołano w 1720 roku, z inicjatywy kurii rzymskiej, synod zamojski [Зноско 1993, 184]. Było to przełomowe wydarzenie w procesie latynizacji Cerkwi unickiej, na którym rozstrzygnięta została jedna z najważniejszych kwestii zbliżenia Cerkwi unickiej z Kościołem łacińskim. Dokonało się to poprzez przyjęcie niektórych dogmatów i obrzędów rzymskokatolickich. Najważniejsze były zmiany w Symbolu Wiary, w nauce o pochodzeniu Ducha Świętego, z dodaniem $i$ od Syna oraz łacińskie nauczanie o czyśćcu, o odpustach, postanowienie soboru trydenckiego w kwestii grzechu pierworodnego, znoszono wschodnie obrzędy [Киприано- 
вич 1894, 169-170; Зноско 1993, 184]. Celem synodu było oczyszczenie unii z resztek prawosławnej tradycji i zastąpienie jej łacińską.

Zmiany dotyczyły eucharystii (zezwolono na odprawianie Świętej Liturgii zarówno na przaśnym, jak i na kwaśnym chlebie), spowiedzi, chrztu, zakazano udzielania Komunii małym dzieciom [Зноско 1993, 184; Киприанович 1894, 169-170]. Zaczęto praktykować bierzmowanie, skasowano post Piotrowy. Do nabożeństw unickich wprowadzono różaniec, upowszechniły się zdrowaśki. Innowacją były tzw. ciche msze czytane, zwane potocznie szeptanymi. Do kalendarza liturgicznego wpisywano łacińskie święta. Upowszechniał się kult świętych rzymskokatolickich, eliminowano nabożeństwa ku czci ruskich świętych [Мiрановіч 2009, 128-129; Киприанович 1894, 170-171]. Wymogiem było modlenie się w czasie nabożeństw w intencji papieża. Święceń kapłańskich udzielano także osobom bezżennym [Зноско 1993, 185]. Zmiany objęły wnętrza świątyń unickich, demontowano ikonostasy, a instalowano ołtarze główne i boczne na wzór łaciński, pojawiły się konfesjonały, ambony, ławki, organy, cyboria, monstrancje itp. [Киприанович 1894, 170]. Cerkwie unickie upodabniały się do kościołów łacińskich.

Pomimo że ryt liturgiczny pozostał wschodni, duchownym zakazano korzystania z dotychczasowych ksiąg, które uznane za skażone schizmą i nakazano spalić. Zastąpiono je wydawnictwami oficyn unickich, uwzględniającymi dogmatyczne i obrzędowe zmiany, wprowadzone przez synod [Зноско 1993, 185].

Proces zmian w świątyniach unickich po synodzie zamojskim doskonale oddają osiemnastowieczne wizyty dziekańskie w Starym Korninie ${ }^{2}$. W wizytacjach z lat 1724, 1727 odnotowano, że w świątyni był jeszcze antimins, żertwiennik (stół ofiarny), carskie wrota, ale pojawiły się już łacińskie szaty liturgiczne - ornaty. W 1727 roku dziekan zalecil, zgodnie z postanowieniami synodu zamojskiego, rano i wieczorem dzwonić na pacierze (na modlitwę) [Из прошлаго 1909, 119]. We wrześniu 1728 roku cerkiew zaopatrzono w nowy antimins, ale i jeden z głównych przedmiotów kultu nieodzownych do odprawiania nabożeństw w Kościele rzymskim portatyl ${ }^{3}$ z czerwonego kamienia, zastępujący antimins. Wizytacja z 1747 roku potwierdza dalsze zmiany. Nie wspominano już o ikonostasie. Wśród książek do nabożeństw

2 Cerkiew w Starym Korninie znana była z kultu Maryjnego. Znajdująca się tam ikona zasłynęła wieloma cudami, które zwyczajem łacińskim były odnotowywane w specjalnej księdze, jaka zachowała się do dziś w archiwum w Petersburgu, drukiem ukazała się w $1997 \mathrm{roku}, \mathrm{z}$ komentarzem Antoniego Mironowicza.

3 Portatyl (portatile) - płaska konsekrowana płyta kamienna, którą z braku konsekrowanego ołtarza kładzie się na mensie, aby w Kościele rzymskokatolickim ołtarz mógł służyć do odprawiania Mszy Swiętej. 
znalazł się służebnik łaciński i Ewangelia w języku polskim. W 1755 roku pojawiła się monstrancja poświęcona w Supraślu w dniu święta Jana Teologa przez biskupa pińskiego. W 1757 roku hetman Jan Klemens Branicki, starosta bielski, kazał wydzielić 1,5 włóki ziemi na utrzymanie organisty. Wizytacja z 1758 roku potwierdza istnienie organów na dziewięć głosów oraz formy do pieczenia opłatków. Zdemontowano natomiast carskie wrota, a zainstalowano ołtarz zgodny z obrządkiem łacińskim, który wyposażono $\mathrm{w}$ trzy antiminsy i dwa rzymskokatolickie portatyle. W 1759 roku dziekan nakazał codziennie rano dzwonić na Anioł Pański. W cyborium były już dwie puszki na Święte Dary, jedne poświęcone w obrządku greckim, a drugie łacińskim. Od 1759 roku nabożeństwa w cerkwi w Starym Korninie odprawiali także księża katoliccy, zgodnie z łacińskim rytuałem. Przy cerkwi był diak i psalmista. Taka sytuacja utrzymywała się do lat 30. XIX wieku [Из прошлаго 1909, 119].

Rozbiory Rzeczypospolitej wpłynęły na zmianę sytuacji Cerkwi unickiej, ale nie wszędzie i od razu. Obwód białostocki, utworzony podczas rokowań pokojowych w Tylży z ziem, które po trzecim rozbiorze Rzeczypospolitej dostały się Prusom, został przyłączony do Rosji w 1807 roku, stąd wcześniejsze rozporządzenia dotyczące unitów nie odnosiły się do tego obszaru.

Polityka rosyjska wobec Cerkwi unickiej zmieniała się wraz z rządami kolejnych władców. W czasach Katarzyny II unici zaczęli masowo przechodzić na prawosławie. Łączny bilans strat Cerkwi unickiej na rzecz prawosławia zdaniem W. Kołbuka wyniósł około 2 milionów wiernych i likwidację czterech biskupstw [Kołbuk 1992, 19]. Następca Katarzyny II był przychylny unitom. W 1797 roku Paweł I dokonał reorganizacji Kościołów obu obrządków. Utworzono dwie nowe diecezje unickie, brzeską i łucką oraz dokonano nowego podziału pozostałych [Ks. Śliwa 1979, 223]. Aleksander I również nie zwalczał unitów, ale po przejściu części unitów na obrządek łaciński wydał dekret zabraniający ich nawracania. Sytuacja zmieniła się za panowania Mikołaja I, który uważał duchownych narodowości białoruskiej i ukraińskiej za osoby powiązane z kulturą wschodnią, które należy pozyskać dla prawosławia [Mironowicz 2006, 469].

Unici mieszkający w późniejszym obwodzie białostockim do trzeciego rozbioru Rzeczypospolitej jurysdykcyjnie podlegali dwóm diecezjom greckokatolickim. Do diecezji metropolitalnej należał dekanat podlaski z 19 parafiami ${ }^{4}$ i nowodworski z 13 parafiami. Diecezja włodzimiersko-brzeska na-

4 Były to parafie: Białystok i Dojlidy, Boguszewo, Choroszcz, Ciecierówka, Dobrowola, Fasty, Gródek, Jałówka, Knyszyn, Kożany, Nowa Wola, Potoka, Puchły, Ryboły, Suraż, Topilec, Topolany, Trześcianka, Wasilków. 
tomiast obejmowała województwo wołyńskie, a na północnym zachodzie województwo brzeskie i podlaskie z okręgami - mielnickim, bielskim i drohiczyńskim [Орловскій 1903, 15]. W Rzeczypospolitej przed 1772 rokiem, według obliczeń W. Kołbuka, było około 9650 parafii unickich. Bazyliańska Prowincja Litewska liczyła 72 klasztory męskie (łącznie 147 męskich i 25 żeńskich) [Kołbuk 1992, 63-64].

Z zagarniętych po trzecim rozbiorze ziem Rzeczypospolitej Prusy utworzyły prowincję Prusy Nowowschodnie, która obejmowała departament płocki i liczący ponad pół miliona ludności białostocki [Wizytacje... 2009, 16-17]. W Prusach Nowowschodnich znalazły się parafie należące do unickiej diecezji metropolitalnej i diecezji brzesko-włodzimierskiej [Wizytacje... 2009, 17]. W styczniu 1797 roku król pruski Fryderyk Wilhelm II powołał nową diecezję supraską, a erekcji dokonał papież Pius VI w marcu 1799 roku z opatem supraskim ks. Teodozjuszem Wisłockim, jako biskupem [Орловскій 1903, 24-25].

Diecezja supraska obejmowała siedemdziesiąt cerkwi w granicach czterech dekanatów (białostocki, bielski, drohiczyński i nowodworski) oraz trzy męskie klasztory bazyliańskie (w Supraślu, Drohiczynie i Kuźnicy) [Орловский 1903, 22-23]. Władze pruskie starały się wprowadzić w diecezji supraskiej nie tylko zmiany jurysdykcyjne, ale także kalendarz gregoriański (w miejsce juliańskiego), próba ta jednak nie powiodła się, ale liczbę świąt poza niedzielami zredukowano do 20 [Kumor 1998, 173-174]. Kanonicznie diecezja supraska nie była związana z żadną metropolią, a podlegała bezpośrednio Stolicy Apostolskiej [Kumor 1979, 174].

Na mocy pokoju w Tylży w 1807 roku obwód białostocki przyłączono do Rosji. W wyniku tych zmian 59 parafii unickich oraz klasztory bazyliańskie w Supraślu, Kuźnicy (założony w 1743 roku) i Drohiczynie (utracono klasztor w Warszawie) dołączono do diecezji brzeskiej. Jedenaście parafii z liczbą 5751 unitów wcielono do Księstwa Warszawskiego ${ }^{5}$, pod zarząd unickiej diecezji chełmskiej [Kołbuk 1992, 126; Jemielity 1974, 157-212].

Liczącą w 1807 roku 52722 wiernych ${ }^{6}$ diecezję supraską zlikwidował Aleksander I w 1809 roku, wiernych włączono do diecezji brzeskiej, a tymi w Księstwie Warszawskim zaopiekował się unicki biskup chełmski [Kumor 1979, 175].

5 Były to cerkwie w Hodyszewie i Wysokiem Mazowieckiem z dekanatu drohiczyńskiego, Tykocinie z dekanatu białostockiego oraz Augustowie, Bali, Hołynce, Lipsku, Łabnie, Perstuniu, Rygałówce, Sopoćkiniach z dekanatu nowodworskiego.

6 Statystyka uwzględniała wyłącznie osoby zdolne do przyjmowania Świętej Komunii, pomijano natomiast dzieci. 
W związku z przyłączeniem diecezji supraskiej do brzeskiej i wzrostem w tej ostatniej liczby cerkwi aż do ponad dziewięciuset, konieczna stała się kolejna reorganizacja. W 1809 roku powołano diecezję metropolitalną (litewską), do której odeszło trzysta parafii z diecezji brzeskiej. Parafie dawnej diecezji supraskiej pozostały w diecezji brzeskiej [Орловскій 1903, 25], która obejmowała gubernię grodzieńską, obwód białostocki oraz cztery powiaty w guberni mińskiej ${ }^{7}$. Biskup Jaworowski zabiegał o ulokowanie w Supraślu brzeskich instytucji biskupich. Sprzeciw metropolity Grzegorza Kochaniewicza, sprawił, że wybrano Żyrowice [Dobrowolski 2003, 83-84].

W 1810 roku nastąpiły kolejne zmiany w strukturze Cerkwi unickiej w Rosji. Tym razem wiernych dwóch dotychczasowych diecezji unickich podzielono pomiędzy cztery (metropolitalną z siedzibą w Wilnie, przy której założono archiwum, arcybiskupstwo w Połocku, biskupstwo brzeskie z siedzibą w Żyrowicach i łuckie w Żydziczynie). Obwód białostocki, obok guberni grodzieńskiej, część mińskiej z powiatami słuckim, pińskim, mozyrskim i rzeczyckim, pozostał w diecezji brzeskiej [Філатава 1998, 9].

W wyniku rozbiorów oraz zmian granic po pokoju w Tylży i Kongresie Wiedeńskim w granicach Rosji znajdowało się pięć diecezji unickich - metropolitalna (wileńska), połocka, włodzimierska, łucka i chełmska na terenie Królestwa Polskiego. W 1816 roku w skład diecezji wileńskiej wchodziło 10 dekanatów, w tym białostocki, bielski, drohiczyński i nowodworski [Radwan 2004, 40].

Po ostatniej reorganizacji z czterech diecezji unickich, utworzono dwie: połocką (białoruską) z siedzibą biskupstwa w Połocku i wileńską (litewską) z konsystorzem w Żyrowicach, dawny obwód białostocki należał do eparchii litewskiej. Kierownictwo Cerkwi unickiej skupiono w powołanym w 1828 roku Greckounickim Kolegium Duchownym w Petersburgu [Орловскій 1903, 58-60; Mironowicz 2006, 468-470].

W latach 20. XIX wieku wyraźnie nasilił się konflikt pomiędzy klerem świeckim i bazylianami. Głównym reprezentantem pierwszego obozu była kapituła brzeska, reaktywowana w 1769 roku. Tworzyło ją sześciu prałatów i dwunastu kanoników. Bazylianie z czasem przejęli wiele cerkwi i parafii, dysponujących dużymi dobrami i funduszami. Dbali o potęge swojego zgromadzenia. Utrzymywali wiele szkół duchownych, najzdolniejszych absolwentów wysyłali na edukację do Rzymu i innych ośrodków zagranicznych. Starali się przy tym nie dopuszczać do oświaty świeckiego duchowieństwa [Орловскій 1903, 29-30, 34]. То w podporządkowaniu sobie szkolnictwa duchownego tkwiła ich siła oddziaływania na unitów. Bazylianie podlegali

7 Były to powiaty: słucki, piński, mozyrski i rzeczycki. 
wyłącznie generałom, zostali wyjęci spod władzy nawet metropolitów. [Киприанович 1894, 21-23]. Zgromadzenie umocniło swoją pozycję jeszcze bardziej za sprawą kasacji zakonu jezuitów. Wstępowanie wyznawców obrządku łacińskiego do zgromadzenia bazylianów stało się powszechną praktyką, a przywilejem, kiedy z czasem zaczęto wymagać od nowicjuszy potwierdzenia szlachectwa [Киприанович 1894, 18-19]. Latynizacji zgromadzenia sprzyjało rozporządzenie władz, na mocy którego archimandrytą i biskupem mogła zostać tylko osoba pochodzenia szlacheckiego [Киприанович 1894, 21-23]. Bazylianie przejęli wiele cerkwi i parafii, dysponujących dużymi dobrami i funduszami [Орловскій 1903, 29-30]. Z czasem skupili w swoich rękach władzę, fundusze, oświatę. W XVIII wieku bazylianie tworzyli niemal „państwo w państwie”. Wszystko to prowadziło do ogromnej niechęci do nich duchowieństwa świeckiego. Natomiast sytuacja bazylianek była nieporównywalnie gorsza. Brak organizacji międzyklasztornej i skąpe uposażenie oznaczało bardziej wegetację ich niż funkcjonowanie. Zdarzało się nawet, że mniszki zmuszone były do żebrania [Kołbuk 1998, 61, 63-64].

Unicki stan duchowny obejmowal parochów i diakonów oraz służbę cerkiewną diaków, ponomarów, zwanych niekiedy potomarami lub zakrystianami, którzy asystowali podczas nabożeństw [Fionik 2005, 178-191], dzwonników i organistów z rodzinami [Запискu... 1883, 63-64]. Duchowni stanowili swoistą kastę. Przez pokolenia synowie parochów zostawali duchownymi. Uposażenie cerkwi traktowano często jak dziedzictwo, do którego tytułem były święcenia kapłańskie [Kołbuk 1998, 247]. Świeckie duchowieństwo unickie, w porównaniu do księży łacińskich, było słabo edukowane [Łubieńska 1911, 13-14], nabywali od ojców lub krewnych praktyki obrzędowej, na elementarnym poziomie opanowywali umiejętności pisania i czytania oraz dysponowali pewnymi środkami, koniecznymi do uzyskania święceń i otrzymania prezenty [Kołbuk 1998, 40].

Święcenia diakońskie i kapłańskie odbywały się według zasad łacińskich, a duchowni otrzymywali w języku polskim bądź po łacinie tzw. „formaty” . Innowacją rzymską było obdarowywanie z tej okazji utensyliami liturgicznymi, za które należało zapłacić [Бобровский 1890, 35]. Podczas święceń kapłańskich i przy mianowaniu na probostwo parochowie składali przysięgę na wierność papieżowi [Запискu... 1883, 19].

Duchownych unickich nazywano parochami, odpowiednio pojawiło się określenie parochia i parochianie. Termin ten wprowadzono w miejsce prawosławnego świaszczennika czy popa ${ }^{9}$ po synodzie zamojskim [Dylągo-

8 Były to dokumenty potwierdzające świecenia diakońskie i kapłańskie.

9 Określenie to z czasem nabrało pogardliwego zabarwienia. 
wa 1996, 36-37]. Z czasem stale używane w Cerkwi określenia zamieniano na polskie, na przykład zamiast pop mówiono ksiadz, zamiast władyka biskup, zamiast archimandryta opat, zamiast cerkiew kościól itp., co miało podnieść prestiż unickich duchownych, ponieważ polski uważany był za język ludzi wykształconych [Dylągowa 1996, 49]. Do użytku codziennego wszedł termin „administrowanie sakramentem”, a „Świętą Liturgię" zastąpiono terminem „Msza Święta” [Bendza 2003, 277].

Latynizacji poddano duchowieństwo, sprzyjała temu zacieśniająca się więź między klerem obu obrządków na stopie towarzyskiej, niekiedy rodzinnej oraz zatrudnianie duchownych unickich, jako wikariuszy przy kościołach jak i posługa duszpasterska księży łacińskich unitom, co jak się okazało niosło jednak pewne zagrożenia [Теплова 1997, 75].

W obwodzie białostockim latynizacji Cerkwi unickiej towarzyszył nasilony proces polonizacji grekokatolików, zwłaszcza kleru [Fionik 2005, 178-191]. Język cerkiewnosłowiański stał się dla kleru niemal obcy, często nie znano już nawet cyrylicy [Теплова 1997, 76]. Zastępowano go językiem polskim, pojawiała się łacina. Język polski ${ }^{10}$ był językiem komunikacji kleru w domu, w szkole i z wiernymi [Орловскій 1903, 30]. Zdarzało się, że żony i córki duchownych unickich oraz służby cerkiewnej wyznawały rzymski katolicyzm, co również sprzyjało polonizacji.

Zmianie uległy kroje szat liturgicznych i stroju noszonego na co dzień. Przywdziewano sutanny, niekiedy zwane sukienkami, z rzędem guziczków po lewej stronie, a na to zakładano surdut. W roku 1747 wprowadzono obowiązek golenia bród i strzyżenia włosów według podanej reguły [Киприанович 1894, 170-171]. W czasie wizytacji świątyń dekanatu podlaskiego z latach 70. XVIII wieku, a zwłaszcza z 1804 roku nowodworskiego ${ }^{11}$, odnotowywano powszechne stosowanie krojów łacińskich [Ksiega wizyty... 1996, 25-26, 31, 53, 59, 78; Записки... 1883, 307].

Latynizacji poddano strój bazylianów, nosili oni długą sutannę z wysokim kołnierzem i wąskimi, zapiętymi wokół nadgarstka, rękawami, przepasaną czarnym pasem. Strojem wyjściowym był czarny płaszcz z kapturem, od którego zwisały dwa końce na kształt stuły. Przełożeni natomiast wkładali płaszcze z szerokimi rękawami. Zimą bazylianie nosili czapki podszyte

10 Do lat 30. XIX wieku nie można mówić o planowej rusyfikacji Imperium Rosyjskie, nie miało wtedy jeszcze wypracowanej polityki kulturalnej wobec tych terenów.

$11 \mathrm{Na}$ wyposażeniu cerkwi w Białymstoku była na przykład stuła, alby, humerały, ornat żałobny, w Choroszczy - dwa aparaty, alby z humerałami, w Fastach - aparaty ze stułą, dwie alby i komże, w Gródku - cztery aparaty, dwie alby z humerałami i paskami, ornat łaciński, w Kożanach - sześć aparatów i dwie alby z humerałami Zakładano powszechnie tzw. łacińskie ornaty, dalmatyki i kapy. 
lisim futerkiem, a latem kapelusze. Włosy z przodu strzygli krótko, natomiast z tyłu były nieco dłuższe. Początkowo bazylianie nosili brody, które potem zaczęli golić (zakonnikom misjonarzom wręcz to nakazywano) [Nabywaniec 1951, 162]. Kanonicy i prałaci, nosili rzymskie distynktorium ${ }^{12}$ [Орловскій 1903, 54-55].

Kleru unickiego, tak jak i duchownych prawosławnych, nie obowiązywał celibat, ale praktykowano także święcenia osób bezżennych.

Podstawowym źródłem utrzymania kleru unickiego była uprawa roli [Łubieńska 1911, 13]. Konieczność pracy fizycznej sprawiała, że z wyższością traktowała unickie duchowieństwo nie tylko szlachta, ale i bazylianie. Niewiele cerkwi zabezpieczonych było odpowiednim nadziałem gruntów funduszowych, stanowiących podstawowe źródło utrzymania. Zdarzało się, że i te były zawłaszczane [Kołbuk 1998, 39].

W 1837 roku dziekan bielski Adam Kostycewicz twierdził, że w tak trudnej sytuacji zbieranie tzw. zdrowasiek było jedynym sposobem polepszenia sytuacji materialnej parochów ${ }^{13}$. Dochody z posługi duszpasterskiej $\mathrm{w}$ tamtych czasach stanowiły śladowe wsparcie finansowe kleru unickiego. $\mathrm{Na}$ synodzie zamojskim pod groźbą ekskomuniki zabroniono duchownym unickim pobierania opłat za udzielanie sakramentów, choć nie wzbraniano dobrowolnych ofiar [Wyczawski 1987-1988, 268]. W tej sytuacji znaczącym źródłem dochodów parochów mogła być pobierana od unitów dziesięcina. Ci jednak często uiszczali ją na rzecz plebanów obrządku łacińskiego [Kolbuk 1998, 39].

Domy, w których mieszkali parochowie z rodzinami, pozostawiały wiele do życzenia. Potwierdza to zapis wizytacyjny z 1822 roku, dotyczący plebanii w Rybołach. Kanonik brzeski Jan Krassowski tak opisał stan budynku: stary, zruynowany $i$ mieszkajacym $w$ nim niebezpieczeństwem przywalenia grozi [Sosna, Fionik 1999, 35-36] a nie był to przypadek odosobniony. Rzadko parochowie mieszkali na plebanii podobnej do tej, jaką znamy z fundacji Jana Walentego Węgierskiego z 1785 roku ze Szczytów. Tam kolator wzniósł drewniany budynek pokryty czerwoną dachówką, obszerny, z sienią, izbą, alkierzem, izbą czeladną i spiżarnią, w której, z wyjątkiem sieni, gdzie użyto cegły, podłogę ułożono z desek [Sosna, Fionik 2005, 65].

12 Distynktorium - zazwyczaj medalion w formie krzyża noszony na łańcuchu przez prałatów i kanoników należących do kapituł.

13 Lietuvos Valstybes Istorijos Archyvas Vilnius (dalej): LVIA Vilnius, ф. 605 Виленская Православная Консистория, оп. 1, д. 3194 Дело священнике Дрогичинской черкви Тьиминском призывавшем в свою иерков Пиярскаго Ксендза Вичевскаго для произнесения проповеди, к. 3 Рапортъ Бельскаго благочиннаго - протоиерея Адама Костыцевича в Литовскую Греко-Унитскую Духовную Консисторию от 21.10.1837 г. 
Intensywnej latynizacji w pierwszej kolejności poddano wnętrza świątyń. Trudno współcześnie odtworzyć wyposażenie podlaskich cerkwi unickich, gdyż w XVIII wieku uległy okcydentalizacji, a w XIX wieku orientalizacji [Tomalska 2010, 560-561].

Ogromne zmiany zachodziły przede wszystkim w spojrzeniu na samą ikonę, która zatracała swój mistyczno-sakralny charakter. Można nawet mówić o wręcz barbarzyńskim traktowaniu kanonicznych ikon pisanych. W Supraślu starynnyje obraza zostały zastąpione malowanymi na płótnie obrazami w stylu włoskim. Zdarzało się, że miejsce ikon pisanych zajmowały nawet papierowe [Рекуц 1997, 69-70]. Ikony pisane na desce nazywane były starymi obrazami, moskiewskimi, staroświeckimi czy z ruska malowanymi. Stare i zniszczone elementy wyposażenia traktowano utylitarnie. Jeden z najstarszych zabytków sztuki cerkiewnej na Podlasiu, prawe skrzydło carskich wrót $\mathrm{z}$ cerkwi parafialnej w Czyżach, datowane na drugą połowę XVI wieku, zachowało się tylko, dlatego, że posłużyło w pierwszej ćwierci XVIII wieku, jako podobrazie dla wizerunku św. Tomasza, który umieszczono w rzędzie apostolskim nowego ikonostasu [Tomalska 2010, 560-561].

Przemiany ikonograficzne, jakie zachodziły w unickiej sztuce sakralnej XVII-XVIII wieku, doprowadziły do wykształcenia się zespołu cech wyróżniających owe ikony. Cechą znamienną obrazów unickich były zmagania bizantyńskiego tradycjonalizmu z zachodnim nowatorstwem, charakterystyczny kontrast pomiędzy linearno-abstrakcyjnym sposobem obrazowania, a modelunkiem światłocieniowym, zbliżającym wizerunek do zachodniego portretu [Tomalska 2010, 560-561].

Unicka ikonografia wypracowała własny charakter. Swoistym emblematem jej identyfikacji są cudowne ikony, zwłaszcza Maryjne, czczone w licznych sanktuariach unickich w Rzeczypospolitej. Charakterystyczne stało się spisywanie ksiąg cudów przy sanktuariach i uroczyste liturgiczne koronacje obrazów ${ }^{14}$, zwane papieskimi. Na obszarze późniejszego obwodu białostockiego cudami, odnotowywanymi w specjalnej księdze, która zachowała się do dziś, słynęła cerkiew unicka w Starym Korninie. W ikonografii unickiej pojawiły się tematy charakterystyczne dla ikonografii zachodniej [Janocha 2010, 498, 526-543], między innymi motyw kielicha z widoczną nad nim kwadratową hostią. Specyficzny unicki wątek ikonograficzny wiąże się także z ideą prymatu papieskiego (Chrystus przekazujący św. Piotrowi klucze

14 Obrzęd koronacji wizerunków Maryjnych wywodzi się z Rzymu z początku XVII wieku. Pierwsza poza Włochami koronacja miała miejsce w Rzeczypospolitej na Jasnej Górze w 1717 roku. Łącznie w XVIII wieku dokonano 28 koronacji, w tym trzech w sanktuariach unickich (Żyrowicach - 1730 r., Chełmie - 1765 r., Poczajowie - 1773 r.), wszystkie one znajdowały się pod opieką bazylianów. [Ks. Janocha 2010, 510-511]. 
Królestwa Niebieskiego). Wyróżnikiem XVIII-wiecznych obrazów unickich są ikony Pokrowy ${ }^{15}$, które zmieniają staroruski temat, wyrażający ideę opieki i wstawiennictwa Matki Bożej nad Kościołem i narodem. W wieku XVIII ewoluował on w kierunku przedstawienia zachodniego zwanego Mater Misericordiae, wyobrażenie Matki Bożej, wyrażającego w innej formie podobną treść (omoforion zamieniono płaszczem jakim Bogarodzica osłaniała wszystkie stany społeczne, duchowieństwo i osoby świeckie). Do charakterystycznych tematów przejętych przez Cerkiew unicką z liturgii rzymskiej i ikonografii łacińskiej należy zaliczyć Najświętsze Serce Jezusa, Niepokalane Poczęcie oraz motywy emblematyczne (monstrancja, skrzyżowane klucze z tiarą papieską, kopuła watykańska, itp.). Jedynym kryterium wyznaniowej przynależności tych obrazów staje się cyrylicki napis, ale i on z czasem ustępuje miejsca polszczyźnie, albo po prostu zanika [Janocha 2010, 543].

Wszystkie cerkwie unickie w obwodzie białostockim wyposażono w obrazy świętych rzymskokatolickich ${ }^{16}$, których kult wprowadzono po synodzie zamojskim [Ksiega wizyty.., 1996, 52, 72, 77, 85-86, 92, 97, 99, 113, 118, 119, 124, 137, 137; Wizytacje... 2009, 126, 134-135, 147, 148], a do niektórych wprowadzono również figury świętych, jak na przykład w Starym Korninie czy Choroszczy - św. Tomasza z Akwinu i św. Jacka [Ksiega wizyty... 1996, 34].

Nieodzownym elementem wyposażenia świątyni unickiej stał się ołtarz główny i ołtarze boczne [Ksiegga cudów... 1997, 2-3]. Wszystkie cerkwie greckokatolickie w obwodzie białostockim miały ołtarz główny wyposażony według obrządku łacińskiego. Przed nim montowano tzw. balaski, odgradzające duchownego od wiernych. Ołtarze główne, były poświęcone Matce Bożej, z wyjątkiem świątyni w Fastach (Chrystus dźwigający Krzyż) i w Gródku (Chrystus ukrzyżowany). W dwóch przypadkach umieszczono na nich obrazy specyficznie rzymskokatolickie, świąt nieuznawanych przez Cerkiew prawosławną - Niepokalanego Poczęcia w cerkwi w Wasilkowie i Wniebowzięcia Matki Bożej w Topilcu [Księga wizyty... 1996, 23, 34, 51, 58, 113,

15 Pokrowa - ikona Matki Bożej Opiekuńczej, osłaniającej omoforionem cały świat. Święto obchodzone uroczyście przez Cerkiew prawosławną 14 października.

16 Potwierdzają to wizyty dziekańskie z ostatniej ćwierci XVIII wieku. Obrazy św. Franciszka posiadały cerkwie unickie w Fastach i Trześciance, Niepokalanego Poczęcia Maryi Panny w Knyszynie, Nowej Woli, Wasilkowie, Nowym Dworze, Najświętszej Panny Częstochowskiej w Kożanach, Nowej Woli, Potoce, Surażu, Topilcu, w Nowym Dworze i w Puchłach, św. Jozafata w Potoce i Nowym Dworze, św. Rocha w Surażu, św. Tadeusza w Nowej Woli, Wniebowzięcia Najświętszej Maryi Panny w Topilcu, św. Salomei w Wasilkowie, Salvatora Mundi (łac. Zbawiciel Świata - Jezus Chrystus, w lewej ręce trzyma jabłko królewskie i glob z krzyżem, zaś prawą błogosławi) w Siderce, w Nowym Dworze, Matki Najświętszej Różańcowej w Nowym Dworze, św. Apolonii w Samohrudzie. 
124, 131]. Nastawy ołtarzowe w cerkwiach unickich były identyczne jak w kościołach łacińskich. Przeważnie miały jedną kondygnację z obrazem w polu głównym, niekiedy ujętym kolumnami. Ozdabiały je dekoracje snycerskie i skrzydła. W świątyniach unickich w ołtarzu głównym było cyborium, czyli tabernakulum, wykonane z drewna, zamykane zameczkiem i drzwiczkami [Kułak 2010, 579].

Jeszcze przed synodem zamojskim zaczęto wprowadzać do cerkwi unickich boczne ołtarze. Jak pokazują wizytacje z lat 1726-1727 na sześćdziesiąt kontrolowanych świątyń czterdzieści już miało boczne ołtarze $[\mathrm{Ku}-$ łak 2010, 584]. Na początku lat 30. XIX wieku we wszystkich cerkwiach unickich w obwodzie białostockim, zwyczajem rzymskokatolickim, stały boczne ołtarze, jeden, dwa (w Gródku, Szczytach [Sosna, Fionik 2005, 62], cztery (w Kożanach), bądź sześć (w Supraślu) ${ }^{17}$. Zazwyczaj była to para bliźniaczych nastaw, ustawionych naprzeciw siebie przed balustradą, która oddzielała prezbiterium od nawy [Kułak 2010, 584]. W dekanacie bielskim zainstalowano je również w cerkwiach filialnych oraz kaplicach cmentarnych w Tyniewiczach i Czyżach, wyjątek stanowiły świątynie na cmentarzu w Klejnikach, Augustowie i Ploskach ${ }^{18}$. Ołtarzom bocznym patronowali święci Cerkwi greckowschodniej, rzadziej święci Kościoła rzymskokatolickiego.

Równolegle z instalacją ołtarzy głównych następował proces usuwania z cerkwi unickich ikonostasów, który rozpoczął się jeszcze przed 1720 rokiem. Wizytacje z lat 1726-1727 pokazują, że tylko nieliczne świątynie nie posiadały ikonostasów [Kułak 2010, 580]. Jeszcze do lat 70. i 80. XVIII wieku w świątyniach unickich zachowały się fragmenty dawnych ikonostasów. W cerkwi w Rybołach, przykładowo w 1773 roku był: oltarz wielki ze skrzydłami od carskich drzwi, rżniętemi, z obrazem Najświętszej Panny [Ksiega wizyty... 1996, 92, 96, 105].

W połowie lat 30. XIX wieku w diecezji litewskiej na około osiemset świątyń ikonostasy pozostawiono w 103 (około 13\%) [Запикu... 1883, 211-213]. W obwodzie białostockim w dekanacie białostockim żadna z siedemnastu cerkwi parafialnych nie posiadała ikonostasu, z wyjątkiem świątyni klasztornej w Supraślu ${ }^{19}$. W dekanacie bielsko-drohiczyńskim ikonostasy

17 LVIA Vilnius, ф. 605 Виленская Православная Консистория, оп 1 д 2245 Дело о упразднении боковых престолов, к. 1 Епископ Иосиф в Литовскую Греко-Унитскую Духовную Консисторию от 27.11.1836 г.

18 LVIA Vilnius, ф. 634 Литовская Греко-Униатская Консистория, оп. 1, д. 4 Дело о усиройстве черквей к. 65-66, Ведомость о устройстве черквей Бельскаго Благочиния от 11.06.1837 г.

19 LVIA Vilnius, ф. 634 Литовская Греко-Униатская Консистория, оп. 1, д. 4 Дело о усиройстве черквей, к. 67-69 Ведомость о усиройстве иерквей Белостокскаго Благочиния 04.06.1837 г. 
zachowały się w pięciu cerkwiach, w Klejnikach, Narodzenia Najświętszej Marii Panny w Bielsku i Narodzenia Najświętszej Marii Panny w Mielniku, w parafialnej św. Mikołaja w Kleszczelach i w Siemiatyczach ${ }^{20}$.

Świątynie unickie w obwodzie białostockim zostały wyposażone w ołtarzyki procesyjne - feretrony. Po obu stronach posiadały wizerunki świętych, często udekorowane wstęgami. Noszone były, tak jak w kościołach rzymskokatolickich, w czasie procesji, które kroczyły zgodnie z zasadą łacińską, w przeciwnym kierunku niż w Cerkwi prawosławnej. Zdarzało się, że i ołtarzyki procesyjne były poświęcane świętym i świętom rzymskokatolickim, na przykład w Nowej Woli - Niepokalanego Poczęcia i św. Tadeusza [Księga wizyty... 1996, 86].

W cerkwiach unickich praktykowano, na wzór zachodni, ustawianie ławek. Księga wizyt dziekańskich dekanatu podlaskiego z lat 70. i 80 . XVIII wieku potwierdza, że ławki były już na wyposażeniu cerkwi unickich między innymi w Łosince [Sosna, Troc-Sosna 2009, 325], Białymstoku, Choroszczy, Fastach, Gródku, Zawykach, Topolanach, Trześciance [Wizytacje... 2009, 103, 148, 153; Ksiega wizyty... 1996, 23, 34, 51, 58, 113, 124, 131], Jacznem, Samohrudzie i Jurowlanach [Wizytacje... 2009, 103, 148, 153].

Muzyka instrumentalna pojawiła się w cerkwiach unickich stosunkowo późno, dopiero pod koniec XVIII wieku i na samym początku XIX wieku [Kułak 2010, 584]. Wprowadzenie muzyki instrumentalnej wymagało zatrudnienia odpowiednio przygotowanych organistów, co eliminowało diaków. Organy w świątyniach unickich w diecezji litewskiej nie były zjawiskiem powszechnym. W 1833 roku posiadało je 86 cerkwi [3anucku... 1883, 265], co stanowiło 10,75\%. Odmiennie kształtowała się sytuacja w obwodzie białostockim. Tam w organy wyposażono blisko połowę (25) cerkwi greckokatolickich $^{21}$, co było wynikiem nasilonego procesu polonizacji i latynizacji na obszarze pogranicza ${ }^{22}$.

20 LVIA Vilnius, ф. 634 Литовская Греко-Униатская Консистория, оп. 1, д. 4 Дело о усиройстве иерквей, к. 64-66, Ведомость о усиройстве иерквей Бельскаго Благочиния 11.06.1837 г.

21 W dekanacie białostockim organy posiadały cerkwie w Rybołach, Puchłach, Dojlidach, Surażu, Potoce, Nowej Woli i Kuźnicy, w bielskim organy ustawiono w Pasynkach, Klejnikach, Narwi, Łosince, Nowym Berezowie, Czyżach - parafialna i cmentarna, Starym Korninie, Trójcy Świętej i sobornej w Bielsku, Rajsku, Boćkach, Brańsku, Maleszach, a w dekanacie drohiczyńskim w Grodzisku, Drohiczynie, Narodzenia Najświętszej Marii Panny w Mielniku i Żerczycach.

22 LVIA Vilnius, ф. 634 Литовская Греко-Униатская Консистория, оп. 1, д. 4 Дело о усиройстве черквей, к. 65-67 Ведомость о устройстве черквей в Белостокской благочинии от 04.06.1837 г.; LVIA Vilnius, ф. 634 Литовская Греко-Униатская Консистория, оп. 1, д. 4 Дело о усиройстве черквей, к. 67-68 Ведомость о устройстве иерквей в Бельской благочинии от 11.06.1837 г. 
W cerkwiach unickich już od XVII wieku instalowano takie typowo łacińskie sprzęty, jak umieszczane przy wejściu kropielnice (zwane fontannami) - naczynia na wodę święconą. Rzadziej pojawiały się konfesjonały. Montowano je zwłaszcza w cerkwiach budowanych już w drugiej połowie XVIII wieku, na przykład w Szczytach (1785 rok). W świątyniach unickich powszechnie korzystano z dzwonków i tzw. sygnaturek, lamp łojowych, baldachimów procesyjnych, form do pieczenia opłatków i chleba eucharystycznego, zgodne z obrządkiem łacińskim.

Wizytacje przeprowadzone w latach 1726-1727 odnotowały pojawienie się w kilku świątyniach ambon. W granicach późniejszego obwodu białostockiego w ambonę wyposażono cerkiew unicką w Starym Korninie [Записки... $1883,584]$. Do połowy lat 30. XIX wieku w dekanacie białostockim posiadały je już wszystkie świątynie ${ }^{23}$. W dekanacie bielsko-drohiczyńskim w ambony zaopatrzono $27^{24}$ cerkwi parafialnych, filialnych i kaplic ${ }^{25}$. Natomiast w całej diecezji zamontowano je w 414 cerkwiach unickich [Записки... 1883, 15].

Wprowadzone w Świętej Liturgii zmiany, spowodowały, że zatraciła ona swój pierwotny charakter. Duchowni uniccy nie odprawiali nabożeństw nocnego czuwania (wsienocznoje bdienije), nie czytali czasow [Teплова 1997, 76]. Rezygnowano często z odprawiania Świętej Liturgii na antiminsie ${ }^{26}$, z czasem przestano używać w czasie mszy utensyliów cerkiewnych zgodnych z obrządkiem greckowschodnim (darochranitielnicy, daronośnicy, kopije, zwiezdicy, diskosu, mirnicy, lżycy kowczega), w ich miejsce sukcesywnie wprowadzano łacińskie - monstrancję, cyborium, mensę, ampułki cynowe, trybularze. Dozwolone stało się korzystanie z chlebów eucharystycznych

23 LVIA Vilnius, ф. 634 Литовская Греко-Униатская Консистория, оп. 1, д. 4 Дело о усиройстве черквей, к. 65-66 Ведомость о устройстве черквей в Белостокской благочинии от 11.06.1837 2.

24 Ambony zainstalowano w cerkwiach unickich w: Szczytach, Pasynkach, Klejnikach, Narwi, Łosince, Nowym Berezowie, Czyżach, Starym Korninie, Orli, Dubiczach Cerkiewnych, Wólce, w Bielsku Świetego Michała (soborna), Świętej Trójcy (parafialna i filialna) i Zmartwychwstania Pańskiego, w Rajsku, Kleszczelach, Andryjankach, Brańsku, Boćkach, Czarnej Wielkiej, Grodzisku, Narojkach, Drohiczynie, Narodzenia Najświętszej Marii Panny w Mielniku, Żerczycach oraz kaplicy cmentarnej w Czyżach. Ambon nie posiadały tylko świątynie w Podbielu, Narodzenia Najświętszej Marii Panny w Bielsku, Hryniewiczach, Kośnej, Maleszach, Ciechanowcu, Siemiatyczach, Żurobicach filialna św. Jerzego w Kleszczelach, Zmartwychwstania Pańskiego w Mielniku oraz kaplicach cmentarne w Klejnikach, Tyniewiczach, Augustowie, Ploskach.

25 LVIA Vilnius, ф. 634 Литовская Греко-Униатская Консистория, оп. 1, д. 4 Дело о усиройстве иерквей, к. 67-69 Ведомость о устройстве иерквей в Бельской благочинии от 04.06.1838 2.

26 Antimins - rodzaj przenośnego ołtarza, zaopatrzony w relikwie, konsekrowany przez biskupa Kościoła wschodniego, jedwabny bądź płócienny obrus ze sceną złożenia Chrystusa do grobu i wizerunkiem czterech Ewangelistów. 
zarówno przaśnych, jak i kwaśnych. Część unitów przystępowała tylko do spowiedzi, pomijając priczaszczenije.

Praktykowano msze częściowo czytane, a częściowo śpiewane z zastosowaniem dzwonków. Zaniedbano wigilie przed uroczystymi świętami, zaniechano nabożeństw $z$ mirowanijem, cerkwie nie posiadały już nawet (wsienocznikow). Odprawiano różaniec wraz z litanią przed Świętym Sakramentem [Орловскій 1903, 185, 232-233]. Modlitwy różańcowe zastępowały akafisty [Dylągowa 1996, 48; Kołbuk 1992, 14]. Zmieniano zasady celebrowania nabożeństw przez biskupów, funkcję diakona pełnił kapłan, a Mikołaj Dałmatow pisał, że w Supraślu nawet priczetnik [Далматов 1892, 393; Ks. Bendza 2003, 281]. Zarzucono jelejopomazanije chorych, a wprowadzono ostatnie namaszczenie. Nie przestrzegano zakazu, tak jak w prawosławiu, pokrewieństwa pomiędzy zawierającymi związek małżeński [Śliwa 1979, 232].

W świątyniach unickich sporadycznie zachowały się ptaszczenice (całuny). W diecezji litewskiej zostało ich 268 [Записки... 1883, 15]. Z czasem płaszczenice zmieniły swoje przeznaczenie i nie były zgodnie z tradycją greckowschodnią wynoszone w Wielki Piątek na środek cerkwi do adoracji wiernym. W dekanacie bielskim, pozostały w nielicznych świątyniach. Oprawiane w ramy, członkowie bractwa cerkiewnego nosili podobnie jak i ikony w czasie procesji paschalnych od Wielkanocy do Święta Wniebowstąpienia27.

Zmieniono zasadę dzwonienia, w ruch wprawiano cały dzwon, podczas gdy w cerkwiach prawosławnych tylko jego serce. Przyjęto polskie zwyczaje, takie jak strzelanie na wiwat $\mathrm{w}$ czasie paschalnego nabożeństwa czy straże (rzeczywiste bądź posągowe) przy grobie Chrystusa w Wielki Piątek [Ruś podlaska... 1995, 25-26].

Wprowadzono nieznany w prawosławiu kult Najświętszego Sakramentu, zabraniając odprawiania mszy po domach, dawania Komunii Świętej dzieciom podczas chrztu. Nakazano duchowieństwu przechowywać Sanctissimum, (przed którym miała palić się wieczna lampka), odnawiany, co tydzień, w cyborium na ołtarzu (nie tak jak w prawosławiu konsekrowane w Wielki Czwartek na cały rok), wystawiano Najświętszy Sakrament do adoracji. Święte Dary przechowywano łacińskim zwyczajem w cyboriach i puszkach [Записки... 1883, 15].

Do unickiego kalendarza liturgicznego wpisano święta łacińskie, Niepokalane Poczęcie, a zwłaszcza uroczyście obchodzone w obwodzie biało-

27 LVIA Vilnius, ф. 605 Виленская Православная Консистория, оп. 1, д. 2381 Дело о дарохранительничах, $\kappa$. 233 Рапортъ Бельского благочинного проточерея Адама Костыцевича в Литовскую Греко-Унитскую Духовную Консисторию от 24.02.1837 2. 
stockim Boże Ciało28 i inne, nasilił się kult rzymskokatolickich świętych. Ks. Tadeusz Śliwa twierdzi, że unici obchodzili dziesięć świąt więcej niż prawosławni [Matus 2010, 82-83; Śliwa 1979, 232-233].

Nie we wszystkich cerkwiach unickich stosowano podczas Świętej Liturgii prosfory, nie korzystano, więc ze znamienników, a tam gdzie były, miały różne wzory ${ }^{29}$. Powszechnie nabożeństwa odprawiano na hostiachiach wszędzie używano opłatków ${ }^{30}$.

Najwcześniej polonizacji w Wielkim Księstwie Litewskim poddała się szlachta Białorusi i Litwy, która doprowadziła na sejmie 1696 roku projekt zamiany języka urzędowego ruskiego na polski. Cyrylicę zastąpiono alfabetem łacińskim [Sahanowicz 2002, 289-290]. Zbiegło się to prawie w czasie z synodem zamojskim i nasileniem się procesu latynizacji i polonizacji w Cerkwi unickiej. Język polski także i dla kleru unickiego stał się mową nobilitującą. Jak zauważył Witold Kołbuk, była to nie tyle latynizacja, co wręcz polonizacja wschodniej Stowiańszczyzny.

Daleko posunięty w obwodzie białostockim proces polonizacji Cerkwi unickiej i jej wiernych, wyraźnie nasilił się w pierwszej ćwierci XIX wieku. Sprzyjały temu rządy pruskie. Język polski był używany przez unitów, w tym też języku prowadzono kancelarię konsystorza w Supraślu. Ks. Bolesław Kumor pisze nawet (choć trudno się z tym, zdaniem zgodzić), że unici w diecezji supraskiej czuli się Polakami [Kumor 1979, 175].

Polonizacji Cerkwi unickiej sprzyjała liberalna polityka początku rządów Aleksandra I i działalność Wileńskiego Okręgu Szkolnego, kontynuującego dzieło Komisji Edukacji Narodowej. Działo się tak za sprawą zorganizowanego przez księcia Adama Czartoryskiego systemu oświaty, którego został kuratorem. Funkcję swoją uważał za misję narodową. Powstanie Wileńskiego Okręgu Szkolnego było wynikiem ogolnopaństwowej reformy oświatowej w Rosji. Uniwersytet w Wilnie z podległym mu szkolnictwem stał się z jednej strony rozsadnikiem idei Oświecenia, z drugiej zaś głównym czynnikiem polonizacji tych ziem [Łatyszonek 1999, 36-37].

28 Największą popularność z czasem zyskało Święto Bożego Ciała. Nazwa ta wśród unitów na terenie obwodu białostockiego nie przyjęła się. Lud nadał świętu własną - Zeleneć, Zieleniec i zaadaptował rzymskokatolickie, ze specyficznym ludowym kolorytem, zwyczaje, zachowując przy tym stronę praktyczną - zwyczaj święcenia ziół.

29 LVIA Vilnius, ф. 605 Виленская Православная Консистория, оп. 1, д. 2886 Дело о знаменниках, к. 19 Рапортъ Льва Маркевича в Литовскую Греко-Унитскую Духовную Консисторию от 26.08.1836 г.

30 LVIA Vilnius, ф. 605 Виленская Православная Консистория, оп. 1, д. 2499 Дело о дискосах, звездах, копиях, дарохранительничах, к. 202 Рапортъ Бельского благочинного протоиерея Адама Костьцевича в Литовскую Греко-Унитскую Духовную Консисторию от 18.02.1837 2. 
Wyłącznie w języku polskim zdobywali edukację teologiczną przyszli duchowni uniccy. Kończyli oni szkoły duchowne bądź seminarium w Wilnie. Na polonizację Cerkwi unickiej wpływ miała również działalność Rosyjskiego Towarzystwa Biblijnego (na jego czele stał książę Aleksander Golicyn, ówczesny minister Oświaty i Wyznań Cudzoziemskich), celem którego było popularyzowanie Pisma Świętego w Rosji w rożnych językach. Wiceprezesem jego terenowego oddziału na obwód białostocki został w 1817 roku biskup Leon Jaworowski [Dobrowolski 2003, 12].

Sprowadzenie wyznania unickiego do rangi religii chłopskiej powodowało, że i w tej warstwie trwał samorzutny proces polonizacji. W XVIII wieku śpiewano, modlono się, głoszono kazania i prowadzono katechizację po polsku. Język polski stał się w Kościele unickim językiem urzędowym [Maroszek 1996, 15]. Na początku XIX wieku w cerkwiach unickich w obwodzie białostockim powszechnie śpiewano godzinki i inne modlitwy w języku polskim, często przy wtórze organów ${ }^{31}$.

W cerkwiach unickich posługiwano się księgami do nabożeństw z wprowadzanymi po synodzie zamojskim zmianami (Filioque oraz wspominanie papieża) [Bendza 2003, 282], korzystano z Ewangelii w języku polskim i mszałów łacińskich. Były to najczęściej druki supraskie, wileńskie, lwowskie, poczajowskie.

Na początku XIX wieku tylko w nielicznych cerkwiach unickich w obwodzie białostockim zachowały się jeszcze ruskie ewangelie, jak je określali wizytujący. Wszystkie natomiast posiadały na wyposażeniu ewangelie w języku polskim ${ }^{32}$, w wielu pojawiały się mszały łacińskie [Ksiega wizyty... 1996, 23-25].

W języku polskim drukowano książki do nabożeństw i zbiory popularnych pieśni, zwane kantyczkami, z których korzystali unici. Na omawianym obszarze na początku XIX wieku powszechnie posługiwano się wydanym w Supraślu w 1799 roku zbiorem Nabożnych pieśni, wśród których były kolędy, pieśni o Matce Bożej Żyrowickiej i teksty Jana Kochanowskiego. Oficyna supraska w dziele polonizacji Cerkwi unickiej w obwodzie białostockim odegrała znaczącą rolę. Druki w języku polskim stanowiły 67\%, po łacinie $10 \%$, języku litewskim $0,22 \%$ i około $23 \%$ w języku cerkiewnosłowiańskim. Wydano łącznie około trzystu druków łacinką i sto dwadzieścia

31 LVIA Vilnius, ф. 605 Виленская Православная Консистория, оп. 1, д. 3194 Дело о священнике Дрогичинской иеркви Тыминском призьвавшем в свою черков Пиярскаго Ксендза Вичевскаго для произнесения проповеди, к. 85-86 Рапортъ Онуфрия Гоголевского от 19.09.1839 а.

32 W cerkwi w Nowym Dworze podano nawet, że była to Ewangelia z naukami księdza jezuity Marcina Kurzenieckiego. 
cyrylicą (wśród, których znaczący procent stanowiły teksty staroobrzędowców) [Марозава 2001, 108-109].

Obok druków supraskich, które sprzyjały polonizacji Cerkwi unickiej, warto także wymienić, co prawda nieliczne, które służyły zachowaniu języka cerkiewnosłowiańskiego, jak cyryliczny cerkiewnosłowiańsko-polski Лeксикон z 1722 roku, wznawiany w 1751, 1756, 1804, adresowany do kleru unickiego, oraz Азбука і Буквар языка словенского [Марозава 2001, 110-111].

Język cerkiewnosłowiański, mocno zniekształcony i niechętnie używany, był jednym z nielicznych już wyróżników obrządku unickiego w Kościele katolickim. Coraz częściej odzywały się głosy zastąpienia go łaciną. Tej używali zwłaszcza bazylianie, była to przeważająca literatura w zbiorach bibliotecznych zgromadzenia [Марозава 2001, 117-118].

Część duchownych unickich, w obwodzie białostockim, nie znała cyrylicy. W tej sytuacji nabożeństwa odprawiano, korzystając z zeszytów, w których alfabetem łacińskim zapisywano fragmenty Świętej Liturgii i innych nabożeństw. W kazaniach natomiast dialekt (mowę chłopską traktowano jako gorszą, pogardliwie nazywając chamską) zastąpiono językiem polskim, który uważano za język nobilitujący [Чистович 1884, 121; Теплова 1997, 76].

Kler unicki zatracił znajomość cyrylicy. Zaniepokojony tym Antoni Sosnowski ${ }^{33}$, obrońca języka cerkiewnosłowiańskiego, świadomy słabej jego znajomości wśród parochów, w 1829 roku zwrócił się do Świątobliwego Synodu z prośbą o 400 rubli na sfinansowanie wydania w Wilnie 3 tys. sztuk modlitewnika w języku cerkiewnosłowiańskim, celem bezpłatnego rozdania w diecezji [Марозава 2001, 110-111].

Obwód białostocki, będący obszarem pogranicza religijnego i etnicznego, bez wątpienia został poddany nasilonemu procesowi latynizacji i polonizacji Cerkwi unickiej. Tu także zachowało się najwięcej pozostałości pounickich w kulturze tradycyjnej i obrzędowości prawosławnej, które po kasacie unii zaadaptowała Cerkiew.

\section{Literatura}

Ks. Bendza M., 2003, Przyrzeczenie dane unitom, „Elpis. Czasopismo Teologiczne Katedry Teologii Prawosławnej Uniwersytetu w Białymstoku", Rocznik V(XVI) zeszyt 7-8 (20-21), s. 164-283.

33 Antoni Sosnowski był to jeden z najbardziej wpływowych duchownych unickich w obwodzie białostockim, proboszcz parafii w Kleszczelach, wieloletni dziekan drohiczyński, kanonik kapituły brzeskiej i oficjał wileński. 
Dobrowolski R., 2003, Opat supraski biskup Leon Ludwik Jaworowski, Supraśl.

Dobrzański Z., 1992, Prawosławni i grekokatolicy w dawnej Polsce, cz. 2, Warszawa. Dylągowa H., 1996, Dzieje Unii Brzeskiej (1596-1918), Warszawa-Olsztyn.

Ks. Hryniewicz W., 1998, Brzeska unia kościelna jako problem ekumeniczny, [w:] Polska-Ukraina. 1000 lat sasiedztwa, t. IV: Katolickie unie kościelne w Europie Środkowej i Wschodniej. Idea a rzeczywistość, Przemyśl, s. 63-70.

Janocha M. ks., 2010, Niektóre aspekty ikonografii unickiej na terenie Rzeczypospolitej, [w:] Śladami unii brzeskiej, Lublin-Supraśl, s. 495-543.

Jemielity W., 1974, Dekanat unicki augustowski $w$ XIX i na poczatku XX wieku, [w:] Materiaty do dziejów społeczno-religijnych w Polsce, Lublin, s. 157-212.

Kołbuk W., 1998, Kościoły Wschodnie w Rzeczypospolitej około 1772 roku, Lublin.

Kołbuk W., 1992, Kościoły wschodnie na ziemiach dawnej Rzeczypospolitej 1772-1914 , Lublin.

Kołbuk W., 1998, Prawo patronatu w Kościele unickim w XVIII-XIX wieku. Zatożenia i funkcjonowanie, [w:] Stowianie Wschodni. Duchowość - Kultura - Język. Ksiega referatów wygłoszonych na sesji jubileuszowej z okazji siedemdziesięciolecia urodzin Profesora Ryszarda Eużnego i profesora Wiesława Witkowskiego, Kraków, s. 37-43.

Kułak A., 2010, Ottarz czy ikonostas?, [w:] Śladami unii brzeskiej, Lublin-Supraśl, s. $577-586$.

Ks. Kumor B., 1979, Kościót unicki w zaborze pruskim. Diecezja w Supraślu (1795-1807), [w:] Historia Kościoła w Polsce, t. II 1764-1945, cz. 1, 1764-1918, Poznań-Warszawa, s. 173-175.

Lewandowski J., 1996, Na pograniczu. Polityka władz państwowych wobec unitów Podlasia $i$ Chetmszczyzny 1772-1875, Lublin.

Łatyszonek O., 1999, Białoruskie Oświecenie, „Białoruskie Zeszyty Historyczne”, nr 2 , s. 35-47.

Maroszek J., 1996, Dziedzictwo unii kościelnej w krajobrazie kulturowym Podlasia 1596-1996, Białystok.

Matus I., 2010, Pounickie pozostałości w roku obrzedowym prawosławnych wsi białoruskich na północnym Podlasiu, [w:] Białorusini - Historia - Kultura, Sesja naukowa Szreniawa 22-26 czerwca 2010, Szreniawa, s. 82-88.

Matus I., 2006, Szkolnictwo cerkiewno-parafialne $w$ powiecie bielskim w latach 1884-1914 na tle sytuacji oświatowej w guberni grodzieńskiej. Z dziejów oświaty ludu białoruskiego na Podlasiu, Białystok.

Mironowicz A., 2006, Kościót prawosławny w Polsce, Białystok.

Ks. Nabywaniec St., 2010, Bazylianie w archidiecezji kijowskiej i ich działalność u schytku I Rzeczypospolitej, [w:] Śladami unii brzeskiej, Lublin-Supraśl, s. $163-177$.

Pidłypczak-Majerowicz M., 2010, Unia brzeska w drukach bazylianów XVII-XVIII wieku, [w:] Śladami unii brzeskiej, Lublin-Supraśl, s. 81-94.

Radwan M., 2004, Carat wobec Kościoła greckokatolickiego w zaborze rosyjskim 1796-1839, Lublin. 
Ruś podlaska. Podlasie w opisach romantyków, 1995, wyboru dokonał i opracował Jerzy Hawryluk, Bielsk Podlaski.

Sahanowicz H., 2002, Historia Białorusi od czasów najdawniejszych do końca XVIII wieku, Lublin.

Ks. Śliwa. T., 1979, Kościót greckokatolicki w zaborze rosyjskim, [w:] Historia Kościoła w Polsce, t. II 1764-1945, cz. 1 1764-1918, Poznań-Warszawa, s. 219-235.

Ks. Śliwa T., 1979, Kościół greckokatolicki na „ziemiach zabranych” (1815-1839), [w:] Historia Kościoła w Polsce, t. II 1764-1945, cz. 1 1764-1918, Poznań-Warszawa, s. 497-502.

Tomalska J., 2010, Unickie ikony na Podlasiu w XVII-XVIII wieku, [w:] Śladami unii brzeskiej, Lublin-Supraśl, s. 559-576.

Ks. Znosko A., 1997, Mały słownik wyrazów staro-cerkiewno-słowiańskich i terminologii cerkiewno-teologicznej, Warszawa.

1996 г., Православное Братство во имя Архистратига Божия Михаила, Минск, c. $69-72$.

Бобровский П., 1889, 1890, Антоний Юръевичъ Сосновский старший соборный протоиерей, "Литовския Епархиальныя Ведомости" 20-22, 45, 47, 49-51/1889; 1-11/1890.

Далматов Н., 1892, Супрасльский Благовещенский Монастыр. Историческо-статистическое описание, Санкт-Петербург.

Прот. Зноско К., 1993, Исторический очерк церковной унии ее происхождение и характер, Москва.

Из прошлаго, 1909, "Гродненския Епархиальныя Ведомости на 1909" г. Духовная Консистория, Гродно, с. 119-121.

Киприанович Г. Я., 1894, Высокопреосьященный Иосиф Семащко митрополит литовский и виленский. Очерк его жизни и деятельности по возсоединению западнорусских униатов с православною черковию в 1839 г., Вильна.

Марозава С. В., 2001, Уніячкая чарква ў этнакультурным развічиі Беларусі (1596-1839 гады), Гродна.

Мірановіч А., 2009, Праваслаўная Беларусь, Беласток.

Орловскій Е., 1903, Судьбы православія в связи с историею латинства и унии в Гродненской губернии в ХІХ столетии (1794-1900), Гродна.

Рекуц И., 1997, Униатстао и культовое искуство Беларуси, [w:] Материальг научно-богословской конференцьи, посвященной памяти преподобномученника Афанасия игумена Брестского и 400-летию Брестских иерковных соборов, Брест, 16-19 сентября Теплова Б., 1997, Влияние латинизачии унии на воссоединение униатов в 1839 г. [w:] Материаль научно-богословской конференцыии, посвященной памяти преподобномученика Афанасия игумена Брестского и 400-летию Брестских иерковных соборов, Брест, 16-19 сентября 1996 г., Минск, с. 75-82 
Філатава А. И., 1998, Хрысиіянскія канфесіі пасля далучэння Беларусі да Расійскай Iмперіi (1772-1860), [w:] Канфесіi на Беларусі (канеи XVIIIXX cm.), Мінск, с. 5-21.

Чистович И. А., 1884, Очерк истории западнорусской черкви, ч. 2, СанктПетербург.

Чистович И., 1882, Очерк истории западнорусской иеркви, ч. 1, Санкт-Петербург.

\section{Archiwa}

Lietuvos Valstybes Istorijos Archyvas Vilnius

ф. 634 Литовская греко-униатская консистория

ф. 605 Виленская Православная Консистория

Дзяржпўны Гістарычны Архій Беларусі ў Мінску

ф. 1744 оп. 1, д. 25 , к. 202- 212, 140 Список лиц Греко Униатского исповедания перешедших на латинский обряд Бельскаго благочиния 1837-1844

\section{Źródła drukowane}

Ksiega cudów przed ikona Matki Bożej w Starym Korninie dokonanych, 1997, oprac. A. Mironowicz, Białystok.

Ksiega wizyty dziekańskiej dekanatu podlaskiego przez mnie księdza Bazylego Gutowskiego dziekana podlaskiego, plebana golniewskiego w roku 1773 miesiaca Novembra dnia 17 iuxta vetus kalendarza sporzadzona, 1996, opracowali Józef Maroszek, Waldemar Wilczewski, Białystok.

Ruś podlaska. Podlasie w opisach romantyków, 1995, wyboru dokonał i opracował Jerzy Hawryluk, Bielsk Podlaski.

Wizytacje cerkwi unickich dekanatu nowodworskiego diecezji supraskiej 1804 roku, 2009, opracowali Przemysław Borowik i Grzegorz Ryżewski, Białystok.

Записки Іосифа Митрополита Литовскаго изданныя Императорскою Академиею Наукъ по завещанию автора, 1883, т. 3, Санкт Петербург.

\section{A VIEW OF UNIATE CHURCH IN THE BIALYSTOK DISTRICT AT THE BEGINNING OF XIX CENTURY}

\section{S U M M A R Y}

Uniate Church in the Republic of Poland was established as a result of the Brest Union in 1596. During the following centuries it evolved towards Latin Church. Mainly on the basis of the adopted by zamoyski synod (1720) resolutions it underwent widespread Latinizing and Polonization. It concerned the dogma, liturgy, church services, rituals, laity and clergy. The interiors of the churches were 
changed, iconostasis, sacrificial tables and altars equipped according to the Greek rite were removed. The main and side altars, confessionals, pulpits, organs and other Latin utensils were introduced instead. The actions of the Basilian congregation were of equal significance. As a result of those changes the Uniate Church gradually wondered off from the eastern rite bringing itself closer to the Latin one. The Polonization was in full swing. Old Slavonic was replaced by Polish. From that moment on this was the language of prayers, sermons, religious singing and communication with the priests. At the turn of the 18th and 19th centuries Polonization of the Unite Church was advanced. The prestige of the clergy and of the Church as an institution didn't raise, what was expected at the moment of introducing the union, the same could be said about its economic situation. All that was leading to the fall. The situation was worsened by the fact that the church founders, most often of the different faith weren't interested in supporting financially the churches of their serfs. The sad picture of the Uniate Church emerges from the deans' inspections from the end of 18th and the beginning of 19th century. In the Bialystok district constituting the religious and ethnic borderland Latinizing and Polonization of the Uniate Church were the most intensive.

Irena Matus e-mail: i.matus@wp.pl 